\title{
Moderating Effect of Trust in Managers on the Relation between Delegation of Authority and Managers' Perceived Social Loafing
}

\author{
*F. Gamze Bozkurt ${ }^{1}$, Azize Ergeneli ${ }^{2}$ \\ ${ }^{1}$ Republic of Turkey Prime Ministry, Privatization Administration, Ankara, Turkey \\ ${ }^{2}$ Hacettepe University, Ankara, Turkey \\ *fgamzebozkurt@gmail.com
}

\begin{abstract}
Delegation of authority is the manager's transferral of his/her right of decision-making and implementation to subordinates. Delegation is widely acknowledged an essential element of effective management. Although delegation of authority is used as a managerial technique, employees might perceive it as either social loafing behaviour by their manager or an empowerment method. One of the purposes of the current study is to determine whether delegation of authority is perceived as a kind of social loafing behaviour or not. According to some researchers, trust affects how one interprets managers' behaviours and the motives underlying them. If employees trust their managers, they become more positive about their managers and may even ignore some of their behaviours. Therefore, the second purpose of the current study is to investigate the moderating effect of trust on the relationship between the delegation of authority and subordinates' perceptions of their managers' social loafing. Data were collected from 243 employees working in a company. Hierarchical regression analysis was used to in order to measure linear and moderator effects. The results revealed that there is no relationship between the delegation of authority and perceived social loafing. Moreover, it was found that the level of trust in managers does not moderate this relationship. Interestingly, although it was not hypothesized, further analysis revealed that trust in manager is negatively related to the manager's perceived social loafing. The implications of the study for research and practice are discussed and some suggestions are made for future research as well as the strengths and limitations of the study.
\end{abstract}

Keywords: Delegation of authority, managers, social loafing, perceived social loafing, trust

\section{Introduction}

Nowadays, it is becoming a type of obligation for managers to share their authority with their employees since organisations have gradually changed into a more complex structure. The number of business segments has increased; competition has accelerated; the value given to human beings within organisations has become important; and there is an effort, through administrative implementation, to comply with the necessities of the age. Although the delegation of authority was a method applied by managers in order to decrease their workload in earlier times, more recently it has been suggested as a means of motivating employees. Some researchers assert that delegation improves the morale of employees. For example, if employees know that they will have to answer for decisions, this will improve the status of their work and provide a motivational factor (Muir, 1995). Moreover, according to some studies, delegation describes a manager's empowerment of an employee to take responsibility activities (Bass, 1990; Wagner, 1994; Konczack, 2000). The understanding of managers and employees about the delegation of authority is also important. Managers might apply the delegation of authority in order to improve the skills of their employees concerning work, to enhance their commitment to the work and organisation, and to make the employees more powerful within the organisation (Yukl and Fu, 1999. On the other hand, some researchers indicate that the volume of supervisors' workloads and the importance of decisions are significant predictors of delegation (Leana, 1986; Leana 1987; Saccardi and Banai, 1994). Delegation is most likely to be aimed at managers because they consider that much of the increased workload is within their work. Managers might therefore delegate to enable them to concentrate their activities on more 'serious' matters (Richards et al., 2000). However, managers might use the delegation of authority as a tool for loafing by offloading their unimportant work. The purpose of the current study consists of discovering how employees perceive the delegation of authority. According to the social exchange theory, delegation of authority is regarded as a social reward or an opportunity, in the form of approval or respect that the manager grants to the subordinate. Whitener et al. (1998) also regarded it as a type of punishment applied by managers to undermine their work. Based on this theory, we assume that delegation might be perceived by employees as social loafing. 
Social loafing refers to a decrease in individual effort due to the social presence of other persons (Bacon et al., 1998). The literature on social loafing focuses on the reasons for the employees' social loafing behaviour. Furthermore, some researchers investigated the effect of employees' colleagues' perception of social loafing behaviour on their loafing behaviour at work (Liden et al., 2004; Piezon and Ferree, 2008; Hung et al., 2009). In the current study, we focus on the manager's perceived social loafing and assume that delegation might be a predictor of a manager's social loafing. On the other hand, the interaction between the manager and the employee is important for delegation of authority. The manager delegates more authority to the employee he/she trusts and the employee accepts and adopts easily the authority delegated by the manager he/she trusts. Employees who trust their managers believe that their managers will protect them and act in good faith in their behaviours. Therefore, trust in the manager is a determinant in the positive or negative consideration of the manager's behaviour (Dirks and Ferin, 2001). In addition, as indicated earlier, much of the research in organisational behaviour appears to position trust as a variable that has direct effects on the relationship between manager and subordinates. Trust could, however, operate on the relationship between manager and subordinates indirectly through a moderating role. While this idea has been relatively unexamined in empirical research, it has been hinted at in conceptual work (Dirks, 1999). One purpose of the current study is to investigate the relationship between the delegation of authority and employees' perceptions of manager's social loafing. The other purpose of the current study is to examine the moderating effect of trust in a manager on the relationship between the delegation of authority and a manager has perceived social loafing. The current study attempts to contribute. The studies in the literature on delegation mostly examine the predictors and reasons for delegation of authority. However, so far no study has examined how employees perceive the delegation of authority. In the current study, we empirically tested whether delegation might be perceived as a manager's social loafing. In addition, in examining the moderating role of trust, this appears to be one of the first studies to empirically test the relationship between delegation of authority and perceived social loafing. If this role is empirically substantiated, then it offers a different way of thinking about trust theoretically and using the concept practically.

\section{Literature Review}

Delegation of authority is defined many ways. Delegation is a process whereby the manager transfers decision-making authority to a subordinate (Leana, 1987). Yukl (1998) asserts that delegation of authority is a tool of organisational effectiveness that involves the assigning of important tasks to subordinates and giving them authority related to decisions if it is firstly approved by the managers, or even without any approval. Delegation of authority is used as a method of participative decision-making (Hodgetts, 1997). However, some emphasises it as distinctly different (Leana, 1986). Although participative management entails the manager-subordinate collaboration in the decision-making process, delegation of authority refers to decisions that the manager allows subordinates to make on their own. In this regard, participation emphasises equality and conformity while delegation encourages achievement and individualism (Strauss, 1963). The movement of human relations, which emphasises the motivation of the employees in the organisation, focuses on delegation of authority in order to motivate the employees and establish a more harmonised workplace. In the studies focusing on the needs and motivations of the employees during the 1940s and 50s, authors such as McGregor, Likert and Argyris argued that decisions should be taken not by the managers but with the participation of employees and the authority of decision-making should be shared among the members of an organisation (Onaran, 1974). With the initiation of the concept of job enrichment in the 1960s, the industrial democracy concept in the 1970s and with the development of the idea of teaming up of employees, the emphasis on internal customer satisfaction, establishing non-hierarchical organisations and delegating authority and responsibility to employees with total quality management in the 1980s, the concept of empowerment emerged (Whetten et al., 1996). With the emergence of the concept of empowerment, the idea that employees should be the authorisation holders came to prominence. Some researcher has defined empowerment as the 'behaviour of a supervisor' who empowers his/her subordinates (Lee and Koh, 2001). On the other hand, the discussions relating to the empowerment concept led to a revision of the concept and how the implementations regarding empowerment were perceived by employees gained importance (Conger and Kanungo, 1988; Spreitzer, 1995). For example, Conger and Kanungo (1988) criticized the literature which described empowerment as authority delegation (Lee and Koh, 2001) and investigated the answers to questions such as "Are subordinates automatically empowered when authority is shared?" According to Conger and Kanungo (1998), if individuals feel the power, the need for power will be met. In the current study, we also examine how the delegation of authority is perceived by the employees. 
A review of the literature indicates that delegation has received wide attention in management practices, but this attention is limited to non-empirical studies and books. Generally, empirical studies follow up two basic lines, which are the predictors and results of the delegation of authority. First, the predictors of delegation of authority are composed of studies performed in order to determine to whom the managers delegate more authority. The results of these studies show that the managers delegate more authority to the employees who are capable, trustworthy, responsible (Leana, 1987; Dewhirst et al., 1987; Saccardi and Banai, 1994) and have worked longer for their managers (Yukl and $\mathrm{Fu}, 1999$ ). On the other hand, Leana (1987) concluded that managers delegate more authority to their employees when they are under a greater workload and they need additional support and the organisational decisions are unimportant. These results show that managerial use of delegation is inversely related to the organisational importance of the decisions involved. For example, if managers do not delegated important work to their employees, they may be perceive their work as trivial and thus may resist delegation. The second line of research has focused on the consequences of the delegation of authority. Several researchers have pointed out the potential benefits of delegation to the subordinates. Positive outcomes such as subordinate performance, job satisfaction, innovative behaviour, task performance, affective commitment, perceived insider status, organisation-based self-esteem and organisational citizenship (Leana, 1986; Schriesheim et al., 1998; Chen and Aryee, 2007; Ansari et al., 2007; Ansari et al., 2009) have been found to strongly relate to delegation. This is the reason why researchers have strongly advocated the use of more delegation in the organisation. Subordinates desire delegation because they feel that they have more control over their work and have increased feelings of self-efficacy (Ansari et al., 2009). Furthermore, if work is distributed equitably and according to skills and experience among the employees, the delegation of authority appears to be a more acceptable tool (Jha, 2004; Weshah, 2012). Jha (2004) suggested that high job characteristics lead to effective delegation. Because of this study, if employees perceive a job is highly motivating, tasks can be easily delegated to them. On the other hand, not all subordinates desire so much autonomy. Some researchers have found that excessive delegation of authority has a negative impact on subordinate performance and job satisfaction (Webber et al., 1985). Therefore, delegation of authority might be an administrative tool of the managers to motivate their employees, to enhance self-competence, as well as being a tool for the managers to loaf at work. For example, Bass (1990) asserts that transformational leaders may use delegation of authority to develop their subordinates. However, a laissez-faire leader may delegate to avoid blame for possible failure. Weiss (1993) pointed out that authority is delegated as the employees perform the tasks well; however, this situation can be perceived as a greater workload and even as a method of punishment that the managers have the employees perform the tasks belonging to them.

According to Nelson (2004) managers might delegate their authority when they feel that their qualifications do not meet their task requirements. On the other hand, he also asserts that managers might prefer not to delegate their authority because of the increased power that the subordinates might have after delegation. Such a situation creates an unfavorable perception of employees towards delegation. Therefore, employees might consider their manager's delegation of their authority as an offloading behaviour instead of a motivator. Based on these assumptions, we assume that the employees might also consider that their managers loaf at work. While the studies in the literature mostly focused on the positive and negative results of the delegation of authority, no study has examined how the employees perceive delegation of authority yet. The employees might perceive delegation of authority by the manager as a positive attempt, as well as it might be perceived as loafing by the manager (Nelson, 2004; Weiss, 1993), and such a perception might affect the behaviour and attitudes of the employees negatively. In the current study, we assume that the employees might perceive delegation of authority as a form of social loafing behaviour by the manager. Social loafing is defined as the tendency for individuals to expend less motivation and efforts when working collectively than when working individually (Karau and Williams, 1997). Latane et al. (1979) pointed out that social loafing is a type of social disease, having negative consequences for individuals, social institutions and societies. During the research on the literature relating to social loafing, it was seen that social loafing literature is limited, with laboratory experimental studies mostly in social psychology (Williams et al., 1981; Kerr and Brunn, 1983; Zaccaro, 1984; Jackson and Williams, 1985). The studies carried out within the organisational behaviour are mostly composed of research to determine the reasons for employees' social loafing. Despite there being a variety of reasons for social loafing, there is a consensus on the reasons behind social loafing, which is based on motivation theories (George, 1992; Kidwell and Bennet, 1993, Liden et al., 2004). While expectancy-value theory is generally used to explain social loafing (Karau and Williams, 1993), there is no motivation theory, which identifies social loafing completely (Knoke, 1988). Expectancy-value theory suggests that individuals are only willing to work hard on a collective task to the degree that they expect their individual efforts to be instrumental in obtaining outcomes that they will personally value. For 
example, when the outcomes tied to the collective situation or the group's performance are not perceived as important, relevant, or meaningful, individuals are unlikely to work hard (Karau and Williams, 1997).

Studies discussing the reasons that lead to social loafing emphasise the importance of the task and its perceived meaningfulness. Some studies suggest that high levels of task meaningfulness or importance might eliminate loafing (Karau and Williams, 1993; Williams and Karau, 1997; Liden et al., 2004). Consistent with the literature about delegation, we assert that if a task, which is given by delegation, is also seen as meaningless or unimportant by the employee, it might be perceived as a manager's social loafing behaviour. The studies in the literature relating to perceived social loafing mostly examine the perception of an employee regarding the social loafing of his/her colleagues and the impact of this perception on the social loafing of the individual. While some studies (Jackson and Harkins, 1985; Piezon and Ferree, 2008) suggested that the perceived loafing has a positive aspect associated with loafing of the individual, other studies (Liden et al., 2004) revealed that there is a negative effect. However, no study has yet examined the factors, which affect the perception of social loafing. In surveying the relevant literature about the delegation of authority, some researchers (Bass, 1990; Weiss, 1993; Nelson, 2004) assert that managers might use delegation as a social loafing tool, but this assumption is not tested empirically. In the current study, we assume that delegation of authority might be a predictor for perceived loafing and we tested this assumption empirically. Given these theoretical arguments and research findings, we offer the following hypothesis. Taking these results in the literature into consideration, it was concluded that whether delegation of authority is a way for a manager to loaf at work or not should be determined by the employees. In the light of this information, the following hypothesis was developed:

Hypothesis-1 (H1): There is a positive relationship between delegation of authority and perceived social loafing.

Trust in the manager is defined as a psychological state comprising a positive expectation that the manager will show interest in their employees' needs and will not disappoint them (Mayer et al.,, 1995; Robinson, 1996; Rousseau et al., 1998). Trust in a manager is also described as an interpersonal trust based on day-to-day interactions between an employee and his or her manager (Stinglhamber et al., 2006). Trust is closely associated with positive expectations. In interpersonal relations, the basic expectation relating to trust is that the counter party will act in good faith and perform its tasks efficiently (Rousseau et al. 1998; Erdem, 2003). For example, if a manager is more trusted, employees are likely to feel safer and more become positive about their manager (Dirks and Ferin, 2002). In contrast, having a low level of trust in a manager is likely to be psychologically distressing when the manager has power over important aspects of one's job, and this distress is likely to affect one's attitudes and perceptions about the workplace and behaviour of the manager (Dirks and Ferin, 2002). Some researchers have shown that trust in managers is positively related to task performance (Aryee and Chen, 2006; Colquitt et al., 2007), job satisfaction (Wech, 2002; Dirks and Ferin, 2002; Mulki et al., 2006) and interactional justice (Holtz and Harold, 2008), and that it is negatively related to turnover (Mulki et al., 2006; Brower et. al, 2009). On the other hand, Huff and Kelly (2003) state that the trust of individuals in their internal group in collectivist cultures is higher than the trust in external groups. Accordingly, an individual in the position of subordinate can ignore some of the attitudes and behaviour of his/her manager and even ignore behaviours of which he/she does not approve on reasonable grounds. Therefore, we assume that high levels of trust might alter the perceptions of the employee about delegation. A recent study carried out in China, which is a collectivistic culture (Chan et al., 2008), indicated that a paternalistic leadership approach is adopted and it is generally accepted that the managers will protect their employees like a father. In other words, the employees working in a collectivist culture might assume that their managers will protect them and will be in good faith in their behaviour towards them. Turkey is a collectivistic culture, too (Hofstede, 1980). In Turkey, the dyadic relationship between a manager and a subordinate may reflect the influence of collectivism (Pellegrini and Scandura, 2006). Because of these findings, we also predict that employees working in Turkish organisations will have a perception that the reason for the delegation of authority cannot be based on a negative cause, such as loafing, because of the high trust in managers.

Indirect support for this prediction can also be found in the leader-member exchange literature. Several studies carried out in different cultures based on leader-member exchange theory have suggested that high-quality leader-member exchange is necessary for effective delegation (Schriesheim et al., 1998; Bauer and Gren, 1996; Yukl and Fu, 1999; Liden et al., 2000; Schyns et al., 2005; Pellegrini and Scandura, 
2006; Ansari et al., 2007). On the other hand, trust plays an important role in the quality of relationships that managers have with their employees (Butler, 1991; Ambrose and Schminke, 2003; Hubbel and Chory-Assad, 2005). Some studies have reported that the quality of the member exchange relationship is strongly associated with trust in the manager (Schriesheim et al., 1998; Dirks and Ferrin, 2002; Wat and Shaffer, 2005; Chen et al. 2008) revealed that the delegation-satisfaction relationship has been more positive for subordinates with high-quality leader-member exchange. The authors interpreted this result as a fact that high-quality exchange is likely to lead to the delegation of more satisfying tasks and to result in subordinates interpreting delegation as supportive and developmental. On the contrary, it can be perceived by the subordinates as their supervisor's off-loading of trivial, unpleasant or disagreeable tasks in cases of low-quality leader-member exchange. This result might mean that, when the employees believe that their managers are reliable, they will probably view their managers as willing to support them to succeed in their task. For example, some researchers suggested that trust in the manager is positively associated with psychological empowerment perceptions (Ergeneli et al., 2007; Barton and Barton, 2011). On the other hand, when employees believe that their managers are not trustworthy, they are more likely to feel that they will not support them if they need it. In the current study, we assume that, if the employees trust his/her managers highly, he/she accepts the delegation of authority as empowering behaviour rather than loafing. However, under low trust, it may be viewed as social loafing behavior. Consistent with these studies and interpretations, one might assume that the trust in one's manager has a moderating effect on the relationship between the delegation of authority and the perceived social loafing of the manager. In other words, delegation of authority is used by the manager as a tool for social loafing in cases of lower trust in managers. Considering this assumption, the second hypothesis of the study is as follows:

Hypothesis-2 (H-2): The trust in a manager will moderate the relationship between the delegation of authority and the manager has perceived social loafing such that delegation of authority relationships will be positively associated with the manager's perceived social loafing for high trust in the manager and negatively associated with the manager is perceived social loafing for low trust in the manager.

\section{Methodology}

Sample: As the relationship between delegation of authority and the manager is perceived social loafing is examined in the current study, an organisational structure was taken into consideration in which the employees can observe the social loafing behaviour of their managers. In this respect, data were collected in a public organisation, which performed as a group in Ankara, Turkey. There are 25 different project groups within the organisation and a head for each project group. It can be said that hierarchical structure is at a low level; 300 are working for the project and the number of members in the teams are equal. The employees participating in the current study were $53 \%$ male and $47 \%$ female. Most of the respondents (55\%) had a graduate degree. Most of the participants (55 \%) that participated in the study had work experience of more than 15 years. The majority of the employees (56\%) were in the range of 40 to 49 years. The length of working time of most respondents with their current managers (40\%) was for more than 15 years.

Data Collection Procedure: Data for the current study were collected through a questionnaire from employees. The questionnaire forms were distributed to the 300 people in the list of employees in the project department, having been obtained from the director of Personnel and Training of the relevant organisation, through face-to-face meetings within three months. In order to protect the confidentiality of the respondents, completed questionnaires were returned directly to the researchers in sealed envelopes. 248 questionnaire forms were returned; however, 5 forms, which had not been filled in properly, were excluded from evaluations. Thus, we received usable questionnaires from 243 employees. The return rate of the questionnaires was $81 \%$.

Measures: Data were obtained from employees. The questionnaires included delegation of authority, perceived manager's social loafing and trust in manager scales. Participants were directed to answer the questions based on their current managers. In the final part of the survey, respondents were asked to provide general demographic and background information. Respondents were asked to indicate their gender, age, educational level, years of work experience, length of their working relationship with their supervisors. Delegation of Authority: We used the scale of Schriesheim et al. (1998) which is based on two three-item scales developed and validated by Schriesheim and Neider (1988) to measure perceived delegation. The scale contains six items to assess delegation of authority. Evidence regarding the 
reliability and validity of the scale was found for research studies conducted in the USA and China (Schriesheim et al., 1998; Chen and Aryee, 2007). A Likert scale enabled the respondents to evaluate each item by providing five alternatives, scoring from 1 (none of the time) to 5 (always). The higher scores indicate high levels of perceived delegation of authority. Perceived social loafing: We used a-thirteen item scale developed by Ülke (2006) to measure social loafing. The scale developed by Ülke (2006) is composed of a total of 13 articles together with 4 items developed in addition to 9 items of the 10 items scale developed by George (1992) for the managers to evaluate the social loafing behaviour of their employees. This scale was developed to measure perceived social loafing by colleagues of an employee. In this study, it was used for the evaluation of the managers' perceived social loafing by the employees. Therefore, items were adapted to allow the employees to evaluate their managers. Responses were recorded so that high values indicate high levels of perceived social loafing. The scale of perceived loafing was applied with a considerable reliability and validity in the studies of Ülke (2006) and Ilgın (2010). Trust in the manager: We used a five item Dyadic Trust Scale developed by Larzelere and Huston (1980) to measure trust. This scale was developed to measure the trust in interpersonal close relationships. Therefore, items were changed so that they refer to the manager rather than a partner. Responses ranged from "Strongly disagree" (1) to "Strongly agree" (5). Responses were recorded so that high values indicated high levels of trust. Demographic variables: The questionnaire included respondents' gender, age marital status, years of work experience and working time with the manager of employees as demographic variables.

In order to determine the reliability of the scales used in this study, Cronbach's Alpha coefficient was used. For the Cronbach's Alpha coefficient, the value of 0.70 recommended by Nunnally (1978) was taken into consideration. On the other hand, total correlation of the items is based on calculation of the correlations between the relevant item given and the whole. It is understood that, if total correlation coefficient is low, the contribution of that question to the whole scale is low. Furthermore, the correlation between the item and the whole should not be negative and should be higher than 0,25 . Otherwise, it is suggested to delete such an item from the scale (Akgül and Çevik, 2003). The Cronbach's Alpha coefficients for the scales used in the study are as follows.

- Delegation of authority (Cronbach's alpha for the scale $=0.69$ )

- Perceived social loafing (Cronbach's alpha for the scale=0.90)

- Trust in manager (Cronbach's alpha for the scale=0.92)

Cronbach's Alpha for the scale of delegation of authority was 0.69 . When the Cronbach's Alpha value was examined, the total item correlation of the $6^{\text {th }}$ question was very low, and when it was deleted from the scale, the Cronbach's Alpha coefficient would be very high. Therefore, it should be removed from the scale. As the Cronbach's Alpha value for the perceived social loafing scale was 0.90 , it can be said that this scale is a highly reliable scale. However, when total correlation of the corrected article was examined, it was determined that the item total correlation of the $2^{\text {nd }}$ question was low. As the Cronbach's Alpha value for the scale of trust manager was 0.92 , it can be said that this scale is a highly reliable scale.

\section{Findings}

Factor analysis was conducted to obtain proof relating to the structure validity of the scales used in this study. The method of analysing basic components in the exploratory factor analysis was used to determine whether the questions in the scales were loaded into their own dimensions or not. The aim of the analysis of principal components is to obtain maximum variance for each component in the data set (Hair et al., 2003). Before application of the exploratory factor analysis, the Kaiser-Meyer-Olkin (KMO) test was conducted to detect conformity of sampling size to factoring. The Bartlett sphericity test was applied to examine the existence of correlation between variables (Hair et al., 2006). In the current study, KMO's value was found to be 0.89 . As KMO's value is higher than 0.60 , it is an acceptable value (Tabachnick and Fidel, 2001). As a result of this finding, it was concluded that the sampling size was suitable for an exploratory factor analysis. As a result of the Bartlett sphericity test, it was concluded that there were significant relationships between variables (Chi-Square $=3260,082, p<0,05$ ), and the data was suitable for factor analysis. After determining the conformity of dataset to factor analysis, factor analysis was conducted for variables such as delegation of authority, the manager's perceived social loafing and trust in the manager. As a result of this analysis, it was determined that the items measuring these variables were collected under 3 factors. The items loaded under 3 factors explain the $54.26 \%$ of total variability. When the factor load of an item is low, it shows that the item is not strongly associated with 
the related factor. Tabachnick and Fidel (2001) suggest that factor load explains the variance well when its value is 0.50 . As a result of the factor analysis, it was found that item two in the scale of perceived social loafing and item six in the scale of delegation of authority were less loaded to their own factors. In the light of the results obtained in validity and reliability analysis made upon all variables in the study, it was decided to delete item 6 in the scale of delegation of authority and item 2 in the scale of the manager's social loafing from the analysis. When these items were deleted and analysis of principal components was conducted again, an interpretable structure of components was obtained. As can be seen in Table 1, the factor loads in Table 1 are the loads rotated by means of varimax method. The objective of the rotation is to reach a theoretically more meaningful and, if possible, simpler factor structure. The varimax method has proved successful as an analytic approach to obtaining an orthogonal rotation of factors. Another reason for using orthogonal factor rotation is that the analytic methods of oblique rotation methods have not been developed completely and contain some contradictions (Hair et al., 2006, p. 126).

Table 1: Principal Components Analysis Factor Loads Matrix

\begin{tabular}{|c|c|c|c|}
\hline & $\begin{array}{l}\text { Delegation } \\
\text { of Authority }\end{array}$ & $\begin{array}{l}\text { Perceived } \\
\text { Social Loafing }\end{array}$ & $\begin{array}{l}\text { Trust in } \\
\text { Manager }\end{array}$ \\
\hline & 1 & 2 & 4 \\
\hline Delegation of Authority 4 & ,86 &,- 18 &,- 04 \\
\hline Delegation of Authority 5 & ,83 &,- 13 &,- 00 \\
\hline Delegation of Authority 2 & ,70 & ,11 & ,20 \\
\hline Delegation of Authority 3 & 64 &,- 14 & 05 \\
\hline Delegation of Authority 1 & 60 & ,12 & ,30 \\
\hline P. Social Loafing 10 &,- 04 & ,80 &,- 06 \\
\hline P. Social Loafing 6 &,- 00 & ,79 &,- 09 \\
\hline P. Social Loafing 7 & ,20 & ,79 &,- 13 \\
\hline P. Social Loafing 9 & ,05 & ,74 &,- 05 \\
\hline P. Social Loafing 11 & ,30 & ,73 &,- 02 \\
\hline P. Social Loafing 12 &,- 07 & ,72 & ,06 \\
\hline P. Social Loafing 8 &,- 07 & ,68 &,- 04 \\
\hline P. Social Loafing 4 & 02 & ,65 & 01 \\
\hline P. Social Loafing 5 & ,05 & ,63 & 05 \\
\hline P. Social Loafing 1 &,- 13 &, 57 & 13 \\
\hline P. Social Loafing 13 &,- 04 & ,56 &,- 18 \\
\hline P. Social Loafing 3 & 05 &, 52 &,- 04 \\
\hline Trust in Manager 3 & 14 &,- 29 & ,88 \\
\hline Trust in Manager 4 & ,08 &,- 28 & ,86 \\
\hline Trust in Manager 2 & ,11 &,- 31 & ,86 \\
\hline Trust in Manager 5 & ,21 &,- 29 & 84 \\
\hline Trust in Manager 1 & ,05 &,- 43 & 62 \\
\hline
\end{tabular}

As a result of reliability and factor analysis, mean and standard deviation values and reliability coefficients were obtained for each variable after the items, which would not be used in the hypothesis analysis, were deleted. These values are reported in Table 2. The hypothesis of the research is associated with the relations between delegation of authority and the manager has perceived social loafing $\left(\mathrm{H}_{1}\right)$ and the moderating effect of the trust in the manager on this relation $\left(\mathrm{H}_{2}\right)$. The hypotheses concerning main and moderating effects were tested by conducting hierarchical multiple regression analyses. Baron and Kenny (1986) define the moderating variable as a quantitative or qualitative variable affecting the strength and/or direction of the relationship between an independent variable and a dependent variable. A moderating variable can increase or decrease the strength of relationship between dependent and independent variables, and sometimes can change the direction thereof. Baron and Kenny (1986) point out that the moderator hypothesis is supported if the interaction term is significant. Before implementing hierarchical multiple regression analysis, the procedure recommended by Aiken and West (1991) was conducted. In the first step, moderating variables and independent variables were centred to eliminate the possibility of multi-correlation between moderating variables. In the second stage, the interaction terms were obtained by multiplying the independent variables and the moderating variable. 
Table 2: Means, Standard Deviations and Reliability Coefficients of Variables

\begin{tabular}{llll}
\hline & Delegation of Authority & Perceived Social Loafing & Trust in Manager \\
\hline Average & 2,56 & 2,36 & 3,52 \\
Std Deviation & 0,05 & 0,04 & 0,07 \\
$\begin{array}{l}\text { Cronbach Alpha } \\
\text { Coefficients }\end{array}$ & 0,80 & 0,91 & 0,92 \\
\hline
\end{tabular}

The following procedure was used to test hypotheses. In the first and second steps, the independent variable (delegation of authority) and moderator variable (trust in manager) were inserted in the analysis, respectively. In the third step, the multiplicative interaction term (delegation of authority $\mathrm{x}$ trust in manager) was added. If the moderator hypothesis were to be confirmed, the beta weight of the interaction term would be significant.

Table 3: Results of Hierarchical Regression for Perceived Social Loafing

\begin{tabular}{lcc}
\hline Variables & I. Step & II. Step \\
\hline Delegation of Authority & 0,02 & 0,02 \\
Trust in Manager & $-0,56$ & $-0,56^{*}$ \\
Delegation of Authority x Trust in Manager & & $-0,00$ \\
F & 53,46 & 35,39 \\
d.f & 2 & 3 \\
$\mathrm{R}^{2}$ & 0,30 & 0,30 \\
$\Delta \mathrm{R}^{2}$ & 0,30 & 0,30 \\
\hline
\end{tabular}

Dependent Variable: The Manager's Perceived Social Loafing ${ }^{*} \mathrm{p}<0,01$

Table 3 presents the results of the hierarchical regression analyses. As can be seen in the table, the relationship between the perceived delegation of authority and the manager is perceived social loafing was not significant $(\beta=0,02, p>0,01)$. Therefore, hypothesis $\mathrm{H}_{1}$ was rejected. As can be seen in Table 3 , the interaction term in the regression was not statistically significant $(\beta=-0,00, p>0,01)$. Therefore, hypothesis $\mathrm{H}_{2}$ was rejected. In other words, trust in the manager had no moderator effect on the relationship between delegation of authority and the perceived social loafing. On the other hand, it was not hypothesis, another finding of the analysis results showed that there was a direct and negative $(\beta=-0,56, p<0,01)$ relationship between trust in the manager and the manager is perceived social loafing.

Discussion: The purpose of this study was to investigate the relationship between delegation of authority and the social loafing behaviour of the manager and the moderating effect of trust in the manager in this relationship. The results revealed that there is no relationship between delegation of authority and the perception of employees regarding the manager's social loafing. In other words, the subordinates participating in the study do not perceive delegation of authority as the manager's social loafing. There are a number of possible explanations for this result. First, this result can be explained through paternalism, which is common in Turkish society (Aycan and Kanungo, 2000). In paternalist societies, the relationship between seniors and subordinates resembles the relationship between parents and children. In this relationship, the task of the senior is to protect, orient, guide the subordinate and make decisions for the benefit of him/her, and to guard him/her like parents (Aycan, 2000). The employees in a paternalist environment perceive the organisation as a fireside, obey their managers, help their managers also in tasks not relating to business, and believe that their managers know the best for themselves, accepting the authority of the manager unconditionally (Erben, 2004). Aycan and Kanungo (2000) in their study revealed that paternalism promotes participating culture and paternalist managers have a managerial understanding, which promotes strengthening of the employees. Delegation of authority in a paternalist society can make the employee feel himself/herself closer to the manager and think that the manager supports him/her. In such cases, it seems natural that delegation of authority is not perceived as the manager's social loafing by the employee. On the other hand, $70 \%$ of the participants comprising the sample of the study were graduates or postgraduates. Previous research in the literature has found that the managers preferred delegating more authority to those employees whose levels of knowledge and skill they found high (e.g. Leana, 1986; Dewhirst et al., 1987). In that case, it can be said that the employees are of the opinion that their managers delegate authority to them as they find them competent, and therefore the delegation of authority is a reward or a positive feedback granted to them due to their successes, rather than social loafing on the part of the manager. Another possible explanation 
relates to the importance or meaningfulness of the delegated task. For example, some studies reveal that high levels of task meaningfulness or importance might eliminate loafing (Karau and Williams, 1993; Williams and Karau, 1997; Liden et al., 2004). Consistent with these findings, if a task, which is given by delegation, is also seen as meaningful and important by the employees, it might not be perceived as a manager's social loafing behaviour.

Furthermore, the study reveals that trust in the manager does not moderate the relationship between delegation of authority and the manager has perceived social loafing. However, an interesting result which was not directly tested in the study but that was found in the analysis of the results is the direct and negative effect of trust in the manager on the manager is perceived social loafing. The negative effect of trust in the manager on the manager is perceived social loafing can be interpreted by the relatively collectivist culture of Turkey (Hosftede, 1980). The culture of a country plays an important role in terms of trust. It is stated that trust develops more easily in collectivist cultures than in individualist cultures (Fukuyama, 1996; Whitener et al., 1998). On the other hand, collectivism may have a greater tolerance towards the behaviour of managers and may feel more compelled to maintain relationships despite minor violations of trust by the manager (Pellegrini and Scandura, 2006). In addition, some researchers assert that trust by itself does not guarantee trustworthy behaviour and, in fact, may lead to even greater fraud than if it were absent (McEvily et al., 2003). For example, according to the results of a study carried out by Yener and Aykol (2010) using an ethnographic research method, the managers can ignore the non-ethical behaviour of employees who they trust. In addition, Holtz \& Harold (2008) suggests that trust in managers is positively related to interactional justice. If employees trust their managers, they might perceive their manager's as being fair. These results are consistent with our findings explains that trust in the manager may decrease the perceptions of the manager's social loafing. In terms of instrumentalism, if trust increases and develops due to the mutual relations between the manager and the employee, the parties get closer to each other and sometimes-personal relations get in the way of organisational requirements. In such a case, it can be thought that an employee can ignore the social loafing behaviour of the manager during their relationship. For example, the results of a study by Schriesheim et al. (1998) demonstrated that delegation of authority has a minor effect on job satisfaction when leader-member exchange is low. Therefore, the degree of trust between the manager and the employee is important for evaluation of the manager's attitudes and behaviour. In other words, close relations between the manager and employees can cause the employees not to perceive the loafing of the manager.

\section{Conclusion}

The findings of the current study suggest that delegation of authority is not perceived by the employees as the manager's social loafing behaviour. The factor, which determines the manager is social loafing, is the trust in the manager. Based on these findings, it can be concluded that trust in the manager is a significant factor in the job environment that shapes employees' perceptions of the behaviour of their managers. The employees regard the manager as loafer at work because of a lack of trust in the manager. This study contributes to the literature in various ways. First, in the literature of organisational behaviour, the previous studies relating to social loafing have mostly focused on social loafing among employees and the perception of an employee relating to social loafing of his/her colleagues. This study specifically attempted to understand the determinants of the manager is perceived social loafing. The results have demonstrated that trust in the manager is a determinant of the manager is perceived social loafing. This study fills a gap in the research on social loafing behaviour by addressing the impact of trust in the manager. Second, the findings of this study suggest that trust is very important factor for the interpretation and evaluation of the manager's behaviour. Third, while it is suggested conceptually in the literature that delegation of authority can be regarded as the manager's social loafing behaviour by the employees, this study empirically demonstrated this proposition.

Practical/Managerial Implications: The findings of the current study have some practical implications for managers and organisations. Managers should not abstain from delegating authority to employees who they consider competent. The employee feels empowered if the manager delegates authority and more willing to take over authority as they feel more empowered. This situation will make it possible for managers to spend more time in managerial work through the delegation of authority. Additionally, the employees will contribute to organisational activities through their ideas and suggestions as they feel more empowered, and therefore the harmony between the employees and the organisation will improve. Furthermore, this study demonstrated that trust in the manager has an important impact on employees' evaluations of their managers' behaviour. Previous researchers have emphasised that trust in managers, 
especially is more important than the trust in colleagues and organisation (Dirks and Ferrin, 2002). Therefore, organizations should also conduct activities that build, develop and sustain trust in managers. This trust in managers will enable employees to contribute more to organisational effectiveness. Effective managers need to gain the trust of their employees. Whitener et al. (1998) argued that the manager should be the starter of a trust relationship. Therefore, the manager should look for ways of enhancing interpersonal trust. Although it may not be possible to have close relationships with every subordinate, it is possible to establish trust relationships that are more satisfying to employees by influencing the perceptions of employees through managerial behaviour.

Directions for Future Research: The results of this study suggest several avenues for future research. This study demonstrated the role that trust plays in managers' perceived social loafing. Although our findings provide the first look at this relationship, we did not directly investigate the underlying processes. We encourage future researchers to investigate explanations for this relationship. Studies may also investigate the differential impacts of such trust based on close relationships by taking into account both its beneficial and detrimental effects on organisations. Therefore, further attention should be given to the measurement of trust in the manager-employee relationship. Scales developed to measure this trust will have better psychometric properties. In addition, future researchers should examine the other determinants that are likely to have an impact on manager's perceived social loafing. For example, researchers might investigate the impact of paternalist leadership behaviour on the manager's perceived social loafing. Another suggestion for further research would be to investigate the relationship between meaningfulness of the task and the manager has perceived social loafing.

Limitations: The current study has a number of limitations that should be addressed in future research. The first limitation of this study is that data was collected from only one organisation. For this reason, the results cannot be generalised. In similar future studies, the employees in different organisations working nationally and internationally can be included in the study. Repetition of the study in different organisations and cultures will contribute to the generalisation of study results. On the other hand, this study is also limited to the project groups in a public organisation. In future studies, the differences between project groups in public and private sectors can be taken into consideration. The second limitation of this study is that it is a cross-sectional design. As data is collected within a specific period in cross-sectional research, causal relations between variables should be interpreted attentively in the study. In future research, a longitudinal design method in which data is collected within different periods can eliminate this limitation. The third limitation of this study is that the data was collected from only one source. It should be noted that data collection from one source may lead to the problem called "common method variance". It is suggested to collect the data from both the managers and the subordinates in order to obtain a more objective measure of the construct (Schriesheim et al., 1998). However, the variables within the scope of this study depend on the perception of the employees. Therefore, the data was collected from the employee himself/herself, as a personal perception cannot be observed by another person.

\section{References}

Aiken, L. S. \& West, S. G. (1991). Multiple Regression: Testing and Interpreting Interactions. Newbury Park, CA: Sage.

Akgül, A. \& Çevik 0. (2003). İstatistiksel Analiz Teknikleri: SPSS'te İşletme Yönetimi Uygulamaları. Ankara: Emek Ofset Ltd. Şti.

Ansari, M. A., Bui L. B. \& Aafaqi R. (2007). Leader- Member Exchange and Work Outcomes: The Mediating role of Perceived Delegation in the Malaysian Business Context. Presented at the Academy of Management (International Management Division), Philadelphia.

Ansari, M. A., Bui L. B. \& Aafaqi R. (2009). Perceived Delegation and Work Outcomes: The Moderating Role of Cultural Orientations in the Malaysian Business Context. Academy of Management, Chicago.

Ambrose, M. L. \& Schminke, M. (2003). Organization Structure as a Moderator of the Relationship Between Procedural Justice, Interactional Justice, 168 Perceived Organizational Support and Supervisory Trust. Journal of Applied Psychology, 88(2), 295-305.

Aycan, Z. \& Kanungo, R. N. (2000). Toplumsal Kültürün Kurumsal Kültür ve İnsan Kaynakları Uygulamaları Üzerine Etkileri. Türkiye'de Yönetim, Liderlik ve İnsan Kaynakları Uygulamaları. İçinde, Aycan Z. (Editör), Ankara: Türk Psikologlar Derneği Yayınları.

Aycan, Z. (2000). Paternalizm: Özgun Yönetim ve Liderlik Anlayışına İlişkin Üç Görgül Çalışma. 8. Ulusal Yönetim ve Organizasyon Kongre Kitabı. May 25-27, Nevsehir. 
Bacon, D. R., Stewart, K. A. \& Stewart-Belle, S. (1998). Exploring Predictors Of Student Team Project Performance. Journal of Marketing Education, 20, 63-71.

Baron, R. M. \& Kenny, D. A. (1986). The Moderator-Mediator Variable Distinction in Social Psychological Research: Conceptual, Strategic, and Statistical Considerations. Journal of Personality and Social Psychology, 51, 1173-1182.

Barton, H. \& Barton C. (2011). Trust and Psychological Empowerment in the Russian Work Context, Human Resource Management, 21 (3), 201-208.

Bass, B. M. (1990). Bass and Stogdill's Handbook of Leadership, Theory and Research and Managerial Application. Third Edition, Newyork: Free Press.

Bauer, T. N. \& Green, S. G. (1996). The Development of Leader- Member Exchange: A Longitudinal Test. Academy of Management Journal, 36(6), 1538-1567.

Brower, H. H., Lester S., Korsgaard, M. A. \& Dineen, B. R. (2009). A Closer Look at Trust in Managers and Subordinates: Understanding the Effects of Both Trusting and Being Trusted on Subordinate Outcomes. Journal of Management, 35(2), 327-347.

Butler, J. K. Jr. (1991). Toward Understanding and Measuring Trust: Evolutions of Conditions of Trust Inventory. Journal of Management, 17, 643-663.

Chan, K. W., Huang, H. \& Ng, P. M. (2008). Managers' Conflict Management Styles and Employee Attitudinal Outcomes: The Mediating Role of Trust. Asia Pacific Journal of Management, 25(2), 277- 295.

Charbonnier, E., Huguet, P., Brauer, M. \& Monteil, J. M. (1998). Social Loafing and Self-beliefs: People's Collective Effort depends on the extent to which They Distinguish Themselves as Better than Others. Social Behavior and Personality, 26(4), 329-340.

Chen, Z. X. \& Aryee, S. (2007). Delegation and Employee Work Outcomes: An Examination of Cultural Context of Mediating Processes in China. Academy of Management Journal, 50, 226-238.

Chen, C. H. V., Chang, W. C. \& Hu, C. S. (2008). The Relationship Between Leader-Member Exchange, Trust, Supervisor Support, and Organizational Citizenship Behavior- A Case Study of Nurses. Journal of Nursing Research, 16(4), 321-328.

Conger, J. A. \& Kanungo, R. N. (1988). The Empowerment Process: Integrating Theory and Practice. Academy of Management Review, 13, 471-482.

Colquitt, J. A., Brent, S. A. \& LePine, J. A. (2007). Trust, Trustworthiness and Trust Propensity: A MetaAnalytic Test of Their Unique Relationships with Risk Taking and Job Performance. Journal of Applied Psychology, 92, 909-927.

Dewhirst, H. D., Metts, V. \& Ladd, R. T. (1987). Exploring the Delegation Decision: Managerial Responses to Multiple Contingencies. Paper presented at the Annual Meeting of the Academy of Management, New Orleans.

Dirks, K. T. (1999). The Effects of Interpersonal Trust on Work Group Performance. Journal of Applied Psychology, 84, 445-455.

Dirks, K. T. \& Ferrin, D. L. (2001). The Role of Trust in Organizational Settings. Organization Science, 12 (4), 450- 467.

Dirks, K. T. \& Ferrin, D. L. (2002). Trust in Leadership: Meta-Analytic Findings and Implications for Research and Practice. Journal of Applied Psychology, 87 (4), 611-628.

Erben, G. S. (2004). Toplumsal Kültür Aile Kültürü Etkileşimi Bağlamında Paternalizm Boyutuyla İşletme Kültürü: Türkiye Örneği. 1. Aile İşletmeleri Kongresi Bildirileri, 17- 18 Nisan 2004, (Editör Koçel, T.), İstanbul: İstanbul Kültür Üniversitesi Yayınları: 345-356.

Erdem, F. (2003). Örgütsel Yaşamda Güven. F. Erdem (Editör). Sosyal Bilimlerde Güven, Vadi Yayınları, Ankara.

Ergeneli, A., Sağlam, G. \& Metin, S. (2007). Psychological Empowerment and Its Relationship to Trust in Immediate Managers. Journal of Business Research, 60, 41-49.

Fukuyama, F. (1996). Trust. The Social Virtues and the Creation of Prosperity. 1st Edition, Newyork: Free Press Paperbacks.

George, J. M. (1992). Extrinsic and Intrinsic Origins of Perceived Social Loafing in Organizations. Academy of Management Journal, 35, 191-192.

Hofstede, G. (1980). Culture's Consequences. International Differences in Work Related Values. Beverly Hills, CA: Sage.

Hair, J. F., Black, W. C., Babin, B. J., Anderson, R. E. \& Tahtam, R. L (2006). Multivariate Data Analysis. New Jersey: Prentice Hall.

Hubbell, A. P. \& Chory-Assad, R. M. (2005). Motivating Factors: Perceptions of Justice and Their Relationship With Managerial and Organizational Trust. Communication Studies, 56(1), 47-70. 
Huff, L. \& Kelley, L. (2003). Levels of Organizational Trust in Individualistic Versus Collectivist Societies: A Seven-Nation Study. Organization Science, 14(1), 81-90.

Hung, T. K., Chi N. W. \& Lu W. N. (2009). Exploring the Relationships Between Perceived Coworker Loafing and Counterproductive Work Behaviors: The Mediating Role of a Revenge Motive. Journal of Business Psychology, 24, 257-270.

Hodgetts, R. M. (1997). Yönetim, Teori, Süreç ve Uygulama. Çevirenler: Canan Çetin ve Esin Can Mutlu, İstanbul: Der Yayınları.

Holtz, B. C. \& Harold, C. M. (2008). When Your Manager Boss Says No! The Effects of Leadership Style and Trust on Employee Reactions to Managerial Explanations. Journal of Occupational and Organizational Psychology, 81, 777-802.

Jackson, J. M. \& Williams, K. D. (1985). Social Loafing on Difficult Tasks: Working Collectively can Improve Performance. Journal of Personality and Social Psychology, 49, 937-942.

Jha, S. (2004). Determinants of Delegation: A Study in Five Star Hotels. Vikalpa, 29(4), 43-55.

Karau, S. J. \& Williams, K. D. (1993). Social Loafing: A Meta-Analytic Review and Theoretical Integration. Journal of Personality and Social Psychology, 65 (4), 681-706.

Karau, S. J. \& Williams, K. D. (1997). The Effects of Group Cohesiveness on Social Loafing and Social Compensation. Group Dynamics: Theory, Research and Practice, 1, 156-168.

Kerr, N. L. \& Brunn, S. E. (1983). Dispensability of Member Effort and Group Motivation Losses: FreeRider Effects. Journal of Personality and Social Psychology, 44, 78-94.

Kidwell, R. E. \& Bennett, N. (1993). Employee Propensity to Withhold Effort: A Conceptual Model to Intersect Three Avenues of Research. Academy of Management Review, 18, 429-456.

Knoke, D. (1988). Incentives in Collective Action in Organizations. American Sociological Review, 53, 311 329.

Konczack, L. J., Stelly, D. J. \& Trusty, M. L. (2000). Defining and Measuring Empowering Leaders Behaviors: Development of Upward Feedback Instrument. In Educational and Psychological Measurement, 60, 301-313.

Larzelere, R. \& Huston, T. (1980). The Dyadic Trust Scale: Toward Understanding Interpersonal Trust in Close Relationships. Journal of Marriage and Family, 42, 595-604.

Latane, B., Williams, K. D. \& Harkins, S. (1979). Many Hands Make the Light the Work: The Causes and Consequences of Social Loafing. Journal of Personality and Social Psychology, 37. 822-833.

Leana, C. R. (1986). Predictors and Consequences of Delegation. Academy of Management Journal, 29(4), 754-774.

Leana, C. R. (1987). Power Relinquishment versus Power Sharing: Theoretical Clarification and Empirical Comparison of Delegation and Participation. Journal of Applied Psychology, 72, 228-233.

Lee, M. \& Koh, J. (2001). Is Empowerment Really a New Concept? International Journal of Human Resource Management, 12(4), 684-695.

Liden, R. C., Wayne, S. J., Jaworski, R. A. \& Benett, N. (2004). Social Loafing: A Field Investigation. Journal of Management, 30(2), 285-304.

Liden, R. C., Wayne, S. J. \& Sparrowe, R. T. (2000). An Examination of the Mediating Role of Psychological Empowerment on the Relations Between the Job, Interpersonal Relationships and Work Outcomes. Journal of Applied Psychology, 85(3), 407-416.

Mayer, R. C., Davis, J. H. \& Schoorman, F. D. (1995). An Integrative Model of Organizational Trust. Academy of Management Review, 20(3), 709-734.

McEvily, B., Perrone, V. \& Zaheer, A. (2003). Trust as an Organizing Principle. Organization Science, 14(1), 91-103.

Muir, J. (1995). Effective Management through Delegation. Work study, 44(7), 6-7.

Mulki, P. J., Jaramillo, F. \& Locander, W. B. (2006). Effects of Ethical Climate and Supervisory Trust on Salesperson's Job Attitudes and Intentions To Quit. Journal of Personal Selling \& Sales Management, 26 (1), 19-26.

Nelson, R. B. (2004). Çalışanlara Yetki Verme. Çeviren: E. Sabri Yarmalı, İstanbul: Hayat Yayıncılık.

Nunnally, J. C. (1978). Psychometric Theory. 2nd Edition, New York: McGraw-Hill.

Onaran, O. (1974). Yetki Göçerimi Yetki devri. Amme İdaresi Dergisi, 7(2). 3-21.

Pabico, J. P., Hermocilla, J. A. C., Galang, J. P. C. \& De Sagun, C. D. (2008). Perceived Social Loafing in Undergraduate Software Engineering Teams, Paper presented at 6th National Conference on Information Technology Education (NCITE 2008) NCAS Auditorium, UP Los Banos.

Pellegrini, E. K. \& Scandura, T. A. (2006). Leader-Member Exchange (LMX), Paternalism and Delegation in the Turkish Business Culture: An Empirical Investigation. Journal of International Business Studies, 37, 264-279. 
Piezon, S. L. \& Ferree, W. D. (2008). Perceptions of Social Loafing in Online Learning Groups: A Study of Public University and U.S. Naval War of College Students. International Review of Research in Open and Distance Learning, 9(2).

Robinson, S. L. (1996). Trust and Breach of the Psychological Contract. Administrative Science Quarterly, 41, 574-599.

Richards, A., Carley, J., Jenkins-Clarke, S. \& Richards, D. A. (2000). Skill Mix Between Nurses and Doctors Working in Primary Care-Delegation or Allocation: A Review of the Literature. Int J Nurs Stud. 37(3), 185-97.

Rousseau, D. M., Sitkin, S. B., Burt, R. S. \& Camerer, C. (1998). Not So Different After All: A Cross-Discipline View of Trust. Academy of Management Review, 23(3), 393-404.

Saccardi, T. A. \& Banai M. (1994). Situational Determinants of the Delegation of Authority among Hospital Senior Executive Officers. Journal of Healthcare Management, 39(2), 237-248.

Schriesheim, C. A. \& Neider, L. L. (1988). Subtypes of Managerial Delegation: An Extension of the Vroom and Yetton Conceptualization. Paper Presented at the Annual Convention of the American Psychological Association, Atlanta.

Schriesheim, C. A., Neider L. L. \& Scandura T. A. (1998). Delegation and Leader-Member Exchange: Main Effects, Moderators and Measurement Issues. Academy of Management Journal, 41, 298-318.

Schyns, B., Paul, T., Mohr, G. \& Blank, H. (2005). Comparing Antecedents and Consequences of LeaderMember Exchange in a German Working Context to Findings in the US. European. Journal of Work and Organizational Psychology, 14(1), 1-22.

Spreitzer, G. M. (1995). Psychological Empowerment in the Work Place: Dimensions, Measurement and Validation. Academy of Management Journal, 38, 1442-1465.

Stinglhamber, F., De Cremer, D. \& Mercken, L. (2006). Perceived Support as a Mediator of the Relationship Between Justice and Trust. Group \& Organization Management, 31(4), 442-468.

Strauss, G. (1963). Some Notes on Power Equalization. In H. Levett (Ed.) The Social Science of Organizations, Engelwood Cliffs, NJ: Prentice-Hall.

Tabachnick, B. G. \& Fidel, L. S. (2001). Using Multivariate Statistics International Student Edition. 4th Edition, USA: Allyn ve Bacon: A Pearson Education Company.

Onaran, O. (1974). Yetki göçerimi Yetki devri. Amme İdaresi Dergisi, 7(2), 3-21.

Ülke, H. (2006). Investigating the Role of Personality and Justice Perceptions on Social Loafing. A Thesis Submitted to the Graduate School of Social Sciences of Middle East Technical University, Ankara.

Wagner, J. A. III. (1994). Participation's Effects On Performance and Satisfaction: A Reconsideration Of Research Evidence. Academy of Management Review, 19, 312-330.

Wat, D. \& Shaffer, M. A. (2005). Equity and Relationship Quality Influences on Organizational Citizenship Behaviors. Personnel Review, 34 (4), 406-422.

Webber, R. A., Morgan, M. A. \& Browne, P. C. (1985). Management-Basic Elements of Managing Organizations. Chicago, IL: Richard D. Irwin.

Wech, B. A. (2002). Trust Context. Business \& Society, 41(3), 353-360.

Weiss, D. H. (1993). Başarılı Ekip Nasıl Yaratılır? (How to Delegate Effectively). Çeviren: Fatmagül Berktay, İstanbul: Rota Yayınları.

Weshah, H. A. (2012). The Perception of Empowerment and Delegation of Authority by Teachers in Australian and Jordanian Schools: A Comparative Study. European Journal of Social Sciences, 31(3), 359-375.

Whetten, D., Cameron K. \& Woods M. (1996). Effective Empowerment \& Delegation. USA: Harper Collins Publishers.

Whitener, E. M., Brodt, S. E., Korsgaard, M. A. \& Werner, J. M. (1998). Managers as Initiators of Trust: An Exchange Relationship Framework for Understanding Managerial Trustworthy Behavior. Academy of Management Review, 23(3), 513-530.

Williams, K., Harkins, S. \& Latané, B. (1981). Identifiability as a Deterrent to Social Loafing: Two Cheering Experiments. Journal of Personality and Social Psychology, 40, 303-311.

Yener, M. İ. \& Akyol Ergun, S. (2010). Güven Üzerine Bir Gensoru: Bir Aile İşletmesinde Güven Kavramının Etnografik İncelemesi. 4. Aile İşletmeleri Kongresi Bildirileri, 16- 17 Nisan 2010, (Editör Koçel, T.), İstanbul: İstanbul Kültür Üniversitesi Yayınları: 197-208.

Yukl, G. \& Fu, P. P. (1999). Determinants of Delegation and Consultation by Managers. Journal of Organizational Behavior, 20, 219-232.

Yukl, G. (1998). Leadership in Organizations. Upper, Saddle River, NJ: Prentice Hall.

Zaccaro, S. J. (1984). Social Loafing The Role of Task Attractiveness. Personality and Social Psychology Bulletin, 10(1), 99- 106. 